\title{
Erratum to: Suppression of Spry4 enhances cancer stem cell properties of human MDA-MB-231 breast carcinoma cells
}

Hongyu Jing ${ }^{1,2}$, Lucy Liaw $^{1}$, Robert Friesel ${ }^{1}$, Calvin Vary' ${ }^{1}$ Shucheng Hua ${ }^{2^{*}}$ and Xuehui Yang ${ }^{1 *}$ (D)

\section{Erratum to: Cancer Cell Int (2016) 16:19 DOI 10.1186/s12935-016-0292-7}

Upon publication of the original article [1], it was noted that the Core Facilities utilized by the authors for their research were not adequately acknowledged in the manuscript. In this case, the following was mistakenly omitted:

Progenitor cell analysis core

Molecular Phenotyping core

Stem Cell COBRE Grant P30GM106391

Vascular Biology COBRE Grant P30GM103392

This has since been acknowledged and corrected in this erratum.

\author{
Publisher's Note \\ Springer Nature remains neutral with regard to jurisdictional claims in pub- \\ lished maps and institutional affiliations. \\ Received: 5 May 2017 Accepted: 5 May 2017 \\ Published online: 11 May 2017

\section{Reference} \\ 1. Jing H, Liaw L, Friesel R, Vary C, Hua S, Yang X. Suppression of Spry4 \\ enhances cancer stem cell properties of human MDA-MB-231 \\ breast carcinoma cells. Cancer Cell Int. 2016;16(1):19. doi:10.1186/ \\ s12935-016-0292-7.
}

*Correspondence: shuchenghua@eyou.com; yangx@mmc.org

${ }^{1}$ Center for Molecular Medicine, Maine Medical Center Research Institute, 81 Research Drive, Scarborough, ME 04074, USA

2 Present Address: Department of Respiratory Medicine, The First Hospital

of Jilin University, Changchun 130021, Jilin Province, China provided you give appropriate credit to the original author(s) and the source, provide a link to the Creative Commons license, and indicate if changes were made. The Creative Commons Public Domain Dedication waiver (http://creativecommons.org/ publicdomain/zero/1.0/) applies to the data made available in this article, unless otherwise stated. 